\title{
Induction of New Defensin Genes in Tomato Plants viaPathogens-Biocontrol Agent Interaction
}

\author{
Hafez EE ${ }^{1 *}$, Hashem M², Mahmoud M Balbaa ${ }^{3}$, El-Saadani MA³ and Seham A Ahmed ${ }^{1}$ \\ ${ }^{1}$ City for Scientific Research and Technology Applications, Arid Lands Cultivations Research Institute, New Borg El-Arab, 21934, Alexandria, Egypt \\ ${ }^{2}$ Faculty of Science, Botany Department, Assiut, 71516, Egypt \\ ${ }^{3}$ Faculty of Science, Department of Biochemistry, Alexandria University, Egypt
}

\begin{abstract}
Defensins and defensin-like peptides are functionally diverse and commonly presented as an immune reaction between plant and pathogen. Trichoderma viride and Bacillus subtilis as biological control agents, were inoculated into the soil, to suppress the activity of the pathogenic fungi Fusarium oxysporum and Rhizoctonia solani on tomato. The up- and down-regulated genes were examined in both treated and non-treated plants, using differential display technique. In treated plants, many up-regulated genes (21) with different molecular sizes, ranging from 50 to 7000 $\mathrm{bp}$, were observed. Only four up-regulated genes were isolated from plants treated with $B$. subtilis $+R$. solani. The sequence analysis revealed that the identified genes were defensin genes; Amino Acid/Auxin Permease Family, Endopolygalacturonase PG1, Fructose-1,6-bisphosphatase and glycosyl transferase. Moreover, chitinase gene, defensin genes (DF1 and DF2) were quantitatively determined using RT-PCR. The comparative expression level of the three induced genes was exponentially increased as a function of time, after the application of the biological control agents. However, while the expression levels of DF1 and DF2 were high in plants infected with either $F$. oxysporum or $R$. solani in the beginning of the experiment, the highest expression level of these genes was attained in the tomato plant treated with either $T$. viride or $B$. subtilis, after 24 hour post inoculation.
\end{abstract}

Keywords: Bacillus subtilis; Defensin; Differential display; Fusarium oxysporum; Rhizoctonia solani; Trichoderma viride

\section{Introduction}

Tomato (Solanum lycopersicum L.) is one of the most economically important crops worldwide; however, it is susceptible to over 200 pathogens that cause severe destruction for this plant and consequent great reduction in the yield. Fusarium oxysporum is the main casual of the tomato root rot disease in tomato plants. Moreover, Rhizoctonia solani are highly destructive pathogens of both greenhouse and field grown tomatoes causing damping-off diseases [1]. Many strategies to control these diseases and others on tomato, have been developed. However, the major component used in integrated pest management (IPM) studies was the chemical fungicides. The implication of chemical fungicides in soil and water pollution has mandated the search for alternative approaches to disease control management [2].

A promising strategy for the replacement of chemicals fungicides has been the implementation of biological control technology, used individually or with other IPM components. Among the promising biological control agents, Trichoderma spp. has attracted the attention for controlling various soil-borne fungi. In addition to the wellrecognized mycoparasitic nature of Trichoderma spp., their role in induction of resistance against pathogens in plants and growth promotion had also been reported [3]. The induction of resistance in plants using Trichoderma spp. has been poorly studied, compared with the responses that are induced by rhizobacteria, perhaps because the Trichoderma research community has focused on factors that are associated with direct effects on other fungi, especially mycoparasitism and antibiosis.

Genetic and gene discovery studies have defined molecular pathways and cellular processes that are transcriptionally regulated during biotic interactions, and have expanded our understanding of how plants respond to pathogens and biological control agents.

Shoresh and Harman [4] reported that proteomic analysis of maize plants inoculated with $T$. harzianum T22 showed a total of 205 differentially expressed spots, over both roots and shoots were identified. Many proteins of defense/stress-related functions were up-regulated. Comparison of the interaction between plants and Trichoderma and plant-Trichoderma-pathogen indicated the activation of specific response to the biocontrol agent. Genes encoding extension like proteins were up-regulated in tomato plants [5], but down-regulated in cacao seedlings by several Trichoderma isolates [6]. Altogether, a whole array of stress- and defense-related proteins are up-regulated or primed in plant shoots, post Trichoderma inoculation of the roots, thus rendering plants to be more resistant to subsequent pathogen attack.

Another example of the biological control agents is the Grampositive bacterium Bacillus subtilis, a bacteria widely distributed in nature, and which has been found to possess bio-control potential for a variety of phytopathogenic fungi [7]. The mechanisms by which $B$. subtilis reduces plant diseases include antagonism of fungal pathogens, by competing for niche and nutriments, by producing fungi-toxic compounds, and stimulating the defensive capacities of the host plant [8]. Yan et al. [7] studied the biocontrol efficiency of B. subtilis SL-13 and its antifungal chitinase. The control efficacies of B. subtilis SL-13 against tomato Rhizoctonia rot were $20.65 \%$ and $35.23 \%$ in the greenhouse and field, respectively.

*Corresponding author: Hafez EE, City for Scientific Research and Technology Applications, Arid Lands Cultivations Research Institute, New Borg El-Arab, 21934, Alexandria, Egypt, E-mail: elsayed_hafez@yahoo.com

Received January 28, 2013; Accepted February 26, 2013; Published March 03 , 2013

Citation: Hafez EE, Hashem M, Balbaa MM, El-Saadani MA, Ahmed SA (2013) Induction of New Defensin Genes in Tomato Plants via Pathogens-Biocontrol Agent Interaction. J Plant Pathol Microb 4: 167 doi:10.4172/2157-7471.1000167

Copyright: @ 2013 Hafez EE, et al. This is an open-access article distributed under the terms of the Creative Commons Attribution License, which permits unrestricted use, distribution, and reproduction in any medium, provided the original author and source are credited. 
The aim of this study was to study the role of application of bioagents (T. viride and B. subtilis), in induction of new specific defense genes against soil-borne pathogens, F. oxysporum and $R$. solani.

\section{Material and Methods}

\section{Plant material and microorganisms}

Tomato plant (Solanum lycopersicum L.) cultivar AUC 93 was obtained from Agricultural Research Center, Giza, Egypt, and used as a test plant in this work. Both pathogens and biological control agents were isolated during this work. Three isolates of Fusarium oxysporum and three of Rhizoctonia solani were isolated from diseased tomato plants showing wilt or root rot symptoms, cultivated in Alexandria governorate, Egypt. The pathogens were cultured on potato dextrose agar (PDA). Trichoderma viride and Bacillus subtilis were isolated from the rhizosphere of healthy tomato plants (from Alexandria governorate, Egypt) on PDA and nutrient agar, respectively.

\section{Pathogenicity test}

The pathogenicity ability of the six isolates of $F$. oxysporum and $R$. solani was evaluated on tomato seedlings (cv. AUC 93) in pots experiment. Tomato seedlings were sterilized ( $5 \mathrm{~min}$ in $0.5 \% \mathrm{NaOCl}$ ), rinsed in sterile distilled water, and seeded in plastic pots, $15 \mathrm{~cm}$ in diameter filled with sterile peat moss and clay $(1: 1 \mathrm{w} / \mathrm{w})$. Inocula were produced by growing the fungi for 15 days at $25^{\circ} \mathrm{C}$ on a milled bran/sand mixture $(1: 1 \mathrm{w} / \mathrm{w})$, autoclaved twice at $120^{\circ} \mathrm{C}$ for $60 \mathrm{~min}$. Bran/sand inoculum was mixed into potting soil at $5 \mathrm{~g}$ per each pot, and seeded with the test plants (10 seeds per pot). For each isolate, 5 replicate pots were scored. The most potent isolates of $F$. oxysporum and $R$. solani were selected for the next experiments, according to this test.

A combined visual disease severity index was used. Each plant was graded on a scale of 0 to 5 , based on the assessment of the disease symptoms degree (wilting, discoloration, and stem, and root rot). To estimate the disease severity (DS), plants were classified into five categories, where $0=$ healthy plant or undetectable symptoms; $1=$ up to $10 \% ; 2=11-25 \% ; 3=26-50 \%, 4=51-75 \%$, and $5=76-100 \%$ of wilting, discoloration and root rot incidence. DS (\%) was assessed twice after 3 and 5 weeks after inoculation, according to the following formula.

$$
\text { Disease severity }=\frac{\sum(\mathrm{ab}) \times 100}{\mathrm{AK}}
$$

Where, $a=$ No. of diseased plants having the same degree of infection, $\mathrm{b}=$ Degree of infection, $\mathrm{A}=$ Total no. of examined plants, and $\mathrm{K}=$ Highest degree of infection.

The mean isolate effect was considered as the sum of DS (\%) in the two periods, according the following formula:

Mean isolate effect $(\mathrm{MIE})=(\mathrm{DS}(\%)$ after 3 weeks+DS (\%) after 5 weeks)/2.

\section{Molecular identification of the microorganisms}

All microorganisms (two tested bioagents and two selected pathogenic fungi) were subjected into DNA extraction, using the Qiagen DNA extraction kit (Qiagen, Germany). These organisms were identified by amplification of ITS gene (in case of fungi) and 16S rRNA gene (in case of bacteria), using universal primers according to Hafez and Elbestawy [9] method. The PCR amplicones were sequenced in Macrogene Company (Seoul, Korea). The DNA sequences were analyzed using the DNA BLAST.

\section{In vitro antagonistic effect of $B$. subtilis and $T$. viride against $F$. oxysporum and $R$. solani}

The antagonistic potentiality of T. viride and B. subtilis was tested against both F. oxysporum (F3) and $R$. solani (R2) in vitro, using dual culture method. PDA plates were inoculated with antagonistic isolated bacteria, as streak line with loop-full of two days old culture, for $48 \mathrm{~h}$ prior to the tested fungi. Mycelial disc (5 $\mathrm{mm}$ in diameter) of an actively growing culture of the tested fungi was placed at a constant distance $(1.0 \mathrm{~cm})$, opposite to other edge of the Petri plate, and incubated at $25^{\circ} \mathrm{C}$ for 3-7 days, and the inhibition zones were measured. To test the antagonistic effect of $T$. viride, $5 \mathrm{~mm}$ discs of advanced edge of one week old PDA culture and the target pathogen (F. oxysporum or $R$. solani) were inoculated at the opposite dish edge of the plate, and incubated at $25^{\circ} \mathrm{C}$ for 7 days. The fungal growth was examined for any change in growth shape or other antagonistic effects. All experiments were carried out with three replicates for each treatment.

\section{Effect of B. subtilis and T. viride against F. oxysporum and $R$. solani under greenhouse conditions}

Antagonistic effect of B. subtilis and T. viride on the growth of $F$. oxysporum and $R$. solani were tested on tomato cultivar AUC 93. Preparation of the inocula of T. viride was made by inoculation of 50 $\mathrm{ml}$ of sterile PD broth medium in $250 \mathrm{ml}$ Erlenmeyer flasks, with 5- $\mathrm{mm}$ plugs taken form a PDA Petri plate cultures (3-7 days-old). Flasks were incubated without shaking in the dark at $25^{\circ} \mathrm{C}$ for a week. Mycelial mat, on the surface of the medium, were then homogenized for 2 min in sterile water and mixed with the soil, at the ratio of $20 \mathrm{ml}$ per pot. For inoculation of $B$. subtilis, the bacterium was inoculated into nutrient broth medium and cultured overnight at $30^{\circ} \mathrm{C}$, with constant shaking. Then, $20 \mathrm{ml}$ of the cell suspension was added to each pot. The biological control agents were added 3 days before transplanting. The inocula of virulent $F$. oxysporum and $R$. solani were prepared as mentioned above (in pathogenicity test), and were added to the soil in the same rate ( $5 \mathrm{~g}$ per pot), one day before tomato transplanting. Healthy control was considered as the treatment to which neither bioagents, nor the pathogens were added. The treatments applied in this study can be summarized as follows: Control (C), R. solani (R), F. oxysporum (F), R. solani $+B$. subtilis (RB), R. solani + T. viride (RT), $F$. oxysporum $+B$. subtilis (FB), and F. oxysporum $+T$. viride (FT). For each treatment, 3 pots were prepared and 10 plants were planted in each pot, with using control for each treatment. The trial was conducted twice and the experiment was arranged in a completely randomized block design. After transplanting, samples from treatments $(\mathrm{C}, \mathrm{RB}$, RT, FB and FT) were taken at different times $(2,4,6,8$, and $24 \mathrm{~h})$, to detect the induced defense genes using differential display technique and real-time PCR [10]. Three plants of each treatment were carefully harvested (Three weeks after inoculation with the pathogen), washed under running water to remove soil particles, and evaluated for the following growth parameters: shoot fresh and dry weights, and root fresh and dry weights. All the weights were expressed in grams; dry weights were recorded after drying the samples at $80^{\circ} \mathrm{C}$ for $48 \mathrm{~h}$ in a hot air oven, until constant weight. Disease severity of each treatment was estimated twice after 3 and 5 weeks after inoculation, according to the above equation in the pathogenicity test.

\section{Extraction of total RNA from plant tissues}

RNA isolation from plant roots (healthy and infected) was done using RNeasy Mini Kit, according to manufacturer's instructions (QIAGEN, Germany). About $0.1 \mathrm{~g}$ of roots was subjected to RNA extraction, 
Citation: Hafez EE, Hashem M, Balbaa MM, El-Saadani MA, Ahmed SA (2013) Induction of New Defensin Genes in Tomato Plants via PathogensBiocontrol Agent Interaction. J Plant Pathol Microb 4: 167 doi:10.4172/2157-7471.1000167

and the resultant RNA was dissolved in diethylpyrocarbonate-treated water. To remove any DNA residue, the extracted RNA was incubated with DNase for one hour at $37^{\circ} \mathrm{C}$. The purified RNA was quantitated spectrophotometrically, and analyzed on $1.2 \%$ agarose gel.

\section{cDNA synthesis for the extracted RNA}

Reverse transcription reactions were performed in reaction volume, $25 \mu \mathrm{l}$. The reaction mixture contains $2.5 \mu \mathrm{l}$ of $5 \mathrm{X}$ buffer with $\mathrm{MgCl}_{2}, 2.5$ $\mu \mathrm{l}$ of $2.5 \mathrm{mM}$ dNTPs, $4 \mu \mathrm{l}$ from oligo $(\mathrm{dT})$ primer $(20 \mathrm{pml} / \mu \mathrm{l}), 2 \mu \mathrm{g}$ RNA and $200 \mathrm{U}$ reverse transcriptase enzyme (MLV, Fermentas, USA). RT-PCR amplification was performed in a thermal cycler (Eppendorf, Germany), programmed at $42^{\circ} \mathrm{C}$ for $1 \mathrm{~h}$ and $72^{\circ} \mathrm{C}$ for $10 \mathrm{~min}$, and the cDNA was then stored at $-20^{\circ} \mathrm{C}$, until used.

\section{Differential display PCR (DD-PCR)}

Six primers were used in the differential display PCR (Table 1). DD-PCR reaction mixture was carried out in total volume $25 \mu \mathrm{l}$, contains $2.5 \mu \mathrm{l} 10 \mathrm{X}$ buffer with $\mathrm{MgCl} 2,2 \mu \mathrm{l} 2.5 \mathrm{mM}$ dNTPS, $1 \mu \mathrm{l} 10$ pmol of each primer, $1.5 \mu \mathrm{l}$ cDNA and $0.2 \mu \mathrm{l}$ (5 units/ $\mu \mathrm{l})$ Taq DNA polymerase. PCR amplification was preformed in a thermal cycler (Eppendorf, Germany), programmed for one cycle at $95^{\circ} \mathrm{C}$ for 5 min, then 34 cycles as follows: $30 \mathrm{sec}$ at $95^{\circ} \mathrm{C}$ for denaturation, one minute at $45-48^{\circ} \mathrm{C}$ for annealing (Table 1 ), and one minute at $72^{\circ} \mathrm{C}$ for elongation. Reaction was then incubated at $72^{\circ} \mathrm{C}$ for $10 \mathrm{~min}$ for final extension. Two $\mu \mathrm{l}$ of loading dye was added prior to loading of $10 \mu \mathrm{l}$ per gel slot. Electrophoresis was performed at 80 Volt with $0.5 \mathrm{X}$ TBE as running buffer in $1.5 \%$ agarose $/ 0.5 \mathrm{X}$ TBE gels, and then, the gel was stained in $0.5 \mu \mathrm{g} / \mathrm{ml}(\mathrm{w} / \mathrm{v})$ ethidium bromide solutions and destained in deionized water. Finally, the gel was visualized and photographed using a gel documentation system. Unique bands that are only present in inoculated host plants, but not in control plants, were cut from the agarose gel and kept at $-20^{\circ} \mathrm{C}$ for further study.

\section{Cloning and sequencing of up-regulated genes}

The PCR-amplified fragments were excised from the agarose gel and purified using Qiagen Gel Extraction kit (Qiagen, Germany). Purified DNA fragments were then cloned into pCR 4-TOPO vector (TOPO TA cloning kit, Invitrogen, USA), in competent Esherichia coli strain TOP 10. Plasmid DNA was isolated using QIA-Spin mini-

\begin{tabular}{|c|c|c|c|}
\hline & Primer & Primer sequence $\grave{3} \rightarrow \mathbf{5}$ & $\begin{array}{l}\text { Annealing } \\
{ }^{\circ} \mathrm{C}\end{array}$ \\
\hline \multirow[t]{6}{*}{$\begin{array}{l}\text { Real time } \\
\text { PCR }\end{array}$} & $\begin{array}{l}\text { Chitinase1 } \\
\text { Forward }\end{array}$ & TTC GTG GAG TGC ATC GGT & \multirow[t]{2}{*}{60} \\
\hline & $\begin{array}{l}\text { Chitinase } 1 \\
\text { Reverse }\end{array}$ & TAN GCN CNN NCC NGG RTT & \\
\hline & $\begin{array}{l}\text { Defensin } 1 \\
\text { Forward }\end{array}$ & CAA TGT AAC TTAAAG TGC CTAATT ATG & \multirow[t]{2}{*}{55} \\
\hline & $\begin{array}{l}\text { Defensin } 1 \\
\text { Reverse }\end{array}$ & CTT ATC AGA TCT CAA TGG AGAAAT C & \\
\hline & $\begin{array}{l}\text { Defnsin } 2 \\
\text { Forward }\end{array}$ & TCA CCAAAC TAT TGG ATT TCAA & \multirow[t]{2}{*}{57} \\
\hline & $\begin{array}{l}\text { Defensin } 2 \\
\text { Reverse }\end{array}$ & GAC TCAATT TIT GAC TTC TTAATC C & \\
\hline \multirow{6}{*}{$\begin{array}{l}\text { Differential } \\
\text { PCR }\end{array}$} & EZ & GCATCACAGACCTGTTATTGCCTC & 45 \\
\hline & Chi 15 & GGYGGYTGGAATGARGG & 55 \\
\hline & EzA1A13 & CAG GCC CTT CCA GCA CCCAC & 53 \\
\hline & Chi 25 & GAYTTRTGGGAATAY CC & 52 \\
\hline & PR1 & $\begin{array}{l}\text { CCCCAAGCTTTTAGTATGGCTTCTC- } \\
\text { GTTCACATAAT }\end{array}$ & 40 \\
\hline & PR2 & $\begin{array}{l}\text { CGCGGATCCTACTGGCTATTCTC- } \\
\text { GATTITTAATCG }\end{array}$ & 40 \\
\hline
\end{tabular}

Table 1: Primers used in this study and their annealing temperature. prep kit (Qiagen, Germany). Plasmid DNA was sequenced in both directions, using BigDye Sequencing Kit and ABI 377 DNA sequencer (Macrogen Inc, Korea). DNA sequences reported in this study were deposited in the NCBI nucleotide sequence database, GenBank.

\section{Alignments and phylogenetic analysis}

Pair wise and multiple DNA sequence alignment were carried out using ClustalW (1.82) [11]. Bootstrap neighbor-joining tree was generated using MEGA 3 [12], from CLUSTALW alignments.

\section{Comparative expression level of chitinase, defensin 1 and defensin 2 genes by quantitative real-time PCR (Q-PCR)}

Tomato leaves samples were taken at different intervals $(2,4,6,8$, and $24 \mathrm{~h}$ ), after inoculation with the pathogens and the bioagents, and the total extraction of RNA of plant tissue was performed as mentioned before. PCR reaction consists of $12.5 \mu$ of 2 X Quantitech SYBR ${ }^{\circledR}$ Green Mix (Fermentaz, USA), $150 \mathrm{ng}$ of cDNA as template, $1 \mu \mathrm{l}$ of $25 \mathrm{pM} /$ $\mu \mathrm{l}$ forward primer, $1 \mu \mathrm{l}$ of $25 \mathrm{pM} / \mu \mathrm{l}$ reverse primer (Table 1), $9.5 \mu \mathrm{l}$ of RNase free water, for a total of $25 \mu$ l. Samples were spun before loading in the rotor's wells. The real time PCR program was performed as follows: initial denaturation at $95^{\circ} \mathrm{C}$ for $10 \mathrm{~min}$; 40 cycles of $95^{\circ} \mathrm{C}$ for $15 \mathrm{sec}$; annealing at $60^{\circ} \mathrm{C}$ for $30 \mathrm{sec}$, and extension at $72^{\circ} \mathrm{C}$ for $30 \mathrm{sec}$. Data acquisition performed during the extension step. This reaction was performed using Rotor-Gene 6000system (Qiagen, USA).

\section{Data analysis}

Comparative quantitation analysis of samples was done using Rotor-Gene-6000 Series Software, based on the following equation.

Ratio target gene expression $=[$ Target gene expression (treatment/ control)/(reference gene/control)]

For estimation, the relative expression of examined genes, realtime PCR results were normalized to $18 \mathrm{~S}$ rRNA gene (Reference gene). The data were statistically evaluated, interpreted and analyzed using Rotor-Gene-6000 version 1.7.

\section{Statistical analysis}

Data were expressed as mean $\pm \mathrm{SD}$, and statistical analyses were performed using the one-way ANOVA, using the Excel program.

\section{Results}

By the end of the isolation trials for the causal agent of wilt, root rot and damping-off diseases from diseased tomato plants, 3 isolates of F. oxysporum and 3 of $R$. solani were obtained. Data presented in table 2 shows that $F$. oxysporum isolate (F3) and $R$. solani isolate (R2) were the most virulent among the tested strains. The isolate main effect of $F$. oxysporum $\mathrm{F} 3$ infection was 46.30 , while $R$. solani $\mathrm{R} 2$ was 71.82 . These two isolates were selected for further studies in this work.

All microorganisms (two tested bioagents and two selected pathogenic fungi) were identified using ITS (in case of fungi) and 16S rRNA (in case of bacteria), and the obtained nucleotide sequences were deposited in the GenBank under accession numbers, which are listed in table 3 .

One way analysis of variance (ANOVA) showed that B. subtilis had a significant antagonistic effect $(\mathrm{P} \leq 0.001)$ on the linear growth of both R. solani (R2) and F. oxysporum (F3). Results obtained in table 4 indicate that the isolate of $R$. solani (R2) was highly antagonized by B. subtilis, and its growth was inhibited by $76.19 \%$. In the same time, the growth of F. oxysporum (F3) was highly suppressed by B. subtilis, 
Citation: Hafez EE, Hashem M, Balbaa MM, El-Saadani MA, Ahmed SA (2013) Induction of New Defensin Genes in Tomato Plants via PathogensBiocontrol Agent Interaction. J Plant Pathol Microb 4: 167 doi:10.4172/2157-7471.1000167

Page 4 of 9

\begin{tabular}{|l|l|l|l|}
\hline \multirow{2}{*}{ Number of isolates } & \multicolumn{2}{|c|}{ DS \% } & MIE significant \\
\cline { 2 - 4 } & Week 3 & Week 5 & \\
\hline F. oxysporum (F1) & $29.83 \pm 0.13$ & $51.04 \pm 0.67$ & $40.44 \pm 0.32$ \\
\hline F. oxysporum (F2) & $30.16 \pm 1.0$ & $50.25 \pm 0.13$ & $40.21 \pm 0.73$ \\
\hline F. oxysporum (F3) & $41.56 \pm 1.01$ & $51.04 \pm 0.33$ & $46.30 \pm 0.4^{*}$ \\
\hline Rhizoctonia solani (R1) & $40.50 \pm 0.2$ & $70.6 \pm 0.34$ & $55.55 \pm 0.49^{* *}$ \\
\hline Rhizoctonia solani (R2) & $50.10 \pm 0.4$ & $93.61 \pm 0.67$ & $71.82 \pm 0.25^{\star * *}$ \\
\hline Rhizoctonia solani (R3 & $46.98 \pm 1.0$ & $60.51 \pm 0.36$ & $53.75 \pm 0.25^{* *}$ \\
\hline LSD (P<0.05) & 1.016 & 0.903 & 0.88 \\
\hline
\end{tabular}

-Values given in the table are the means of three replications (mean $\pm S D$ ) -DS=disease severity and $\mathrm{MIE}=$ mean isolate effect. ${ }^{*}=$ significant ${ }^{* * *}=h i g h$ significant.

Table 2: Pathogencity test for different isolates of $F$. oxysporum and Rhizoctonia solani on tomato after 3 and 5 weeks from infection.

\begin{tabular}{|l|c|}
\hline Name & Accession number \\
\hline Bacillus subtilis & GU393320 \\
\hline Fusarium oxysporum (F3) & HQ438698 \\
\hline Trichoderma viride & HQ438699 \\
\hline Rhizoctonia solani (R2) & FJ588592 \\
\hline Amino Acid/Auxin Permease (AAAP) Family & HS411970 \\
\hline Endopolygalacturonase PG & HS411971 \\
\hline Fructose-1,6 bisphosphatase & HS411972 \\
\hline Glycosyl transferase group 1 & HS411973 \\
\hline
\end{tabular}

Table 3: Accession numbers of microorganisms and isolated genes used in the study.

\begin{tabular}{|l|l|l|l|}
\hline Antagonist & Pathogen & $\begin{array}{l}\text { Linear growth } \\
\text { (cm) }\end{array}$ & $\begin{array}{l}\text { Growth inhibition } \\
\text { Significant (\%) }\end{array}$ \\
\hline \multirow{2}{*}{ Bacillus subtilis } & Rhizoctonia solani (R2) & $2.67 \pm 0.04$ & $76.19 \pm 0.018^{* * *}$ \\
\cline { 2 - 4 } & F. oxysporum (F3) & $2.27 \pm 0.02$ & $40.48 \pm 0.055^{*}$ \\
\hline $\begin{array}{l}\text { Trichoderma } \\
\text { viride }\end{array}$ & Rhizoctonia solani (R2) & $1.53 \pm 0.027$ & $79.6 \pm 0.13^{\star * *}$ \\
\hline LSD (P<0.05) & 0.0618 & $0.93 \pm 0.02$ & $77.11 \pm 0.084^{* *}$ \\
\hline
\end{tabular}

-Values given are the means of three replications $($ mean $\pm S D){ }^{*}=$ significant $^{* * *}=$ hig significant.

Table 4: Antagonistic effect of Bacillus subtilis and Trichoderma viride on the linear growth of different strains of Rhizoctonia solani and F. oxysporum.

\begin{tabular}{|l|l|l|}
\hline Treatment & DS \% & Week 5 \\
\cline { 2 - 3 } & Week 3 & 0 \\
\hline C & 0 & 0 \\
\hline B & 0 & 0 \\
\hline T & 0 & $80.7 \pm 1.0$ \\
\hline R & $66.3 \pm 1.0$ & $86.7 \pm 1.0$ \\
\hline F & $78.3 \pm 0.7$ & $50.3 \pm 0.1$ \\
\hline RB & $30.2 \pm 1.0$ & $57.0 \pm 0.3$ \\
\hline RT & $33.3 \pm 1.0$ & $43.3 \pm 0.4$ \\
\hline FB & $30.6 \pm 0.3$ & $50.7 \pm 0.7^{* * *}$ \\
\hline FT Significant & $33.1 \pm 0.4^{* *}$ & 1.0 \\
\hline LSD $(P \leq 0.05)$ & 1.2 & \\
\hline
\end{tabular}

$\mathrm{DS}=$ disease severity, $\mathrm{C}=\mathrm{control}, \mathrm{B}=$ Bacillus subtilis, $\mathrm{T}=$ Trichoderma viride, $\mathrm{R}=$ Rhizoctonia solani, $\mathrm{F}=\mathrm{F}$. oxysporum, $\mathrm{RB}=$ Rhizoctonia solani+Bacillus subtilis, $\mathrm{RT}=$ Rhizoctonia solani+Trichoderma viride, $\mathrm{FB}=\mathrm{F}$. oxysporum+Bacillus subtilis and $\mathrm{FT}=F$. oxysporum+Trichoderma viride ${ }^{*}=$ significant ${ }^{* * *}=$ high significant.

Table 5: Effect of Bacillus subtilis and Trichoderma viride on disease severity.

by $40.48 \%$. On the other hand, both isolates of $R$. solani (R2) and $F$. oxysporum (F3) were greatly inhibited, as a result of application of $T$. viride in the dual culture test (79.6 and $77.11 \%$, respectively).

Under greenhouse conditions, B. subtilis and T. viride were shown to be effective in reduction of the disease severity on tomato $\mathrm{cv}$ AUC 93, when applied in mix with F. oxysporum and R. solani, compared to soil infested only with the pathogens. Data presented in table 5 show

\begin{tabular}{|l|l|l|}
\hline Treatment & Shoot dry weight $\mathbf{( g )}$ & Root dry weight $\mathbf{( g )}$ \\
\hline C & $3.64 \pm 1.0$ & $0.55 \pm 0.3$ \\
\hline B & $3.51 \pm 0.9$ & $0.09 \pm 0.4$ \\
\hline T & $3.91 \pm 1.1$ & $0.85 \pm 0.7$ \\
\hline R & $0.37 \pm 0.8$ & $0.03 \pm 1.0$ \\
\hline F & $0.17 \pm 0.7$ & $0.07 \pm 0.8$ \\
\hline RB & $2.82 \pm 1.0$ & $0.40 \pm 0.9$ \\
\hline RT & $2.91 \pm 0.6$ & $0.54 \pm 0.3$ \\
\hline FB & $3.22 \pm 1.1$ & $0.50 \pm 0.8$ \\
\hline FT & $3.85 \pm 0.3$ & $0.62 \pm 0.4$ \\
\hline LSD $(P \leq 0.05)$ & 1.2 & 0.4 \\
\hline
\end{tabular}

$-\mathrm{C}=$ control, $\mathrm{B}=$ Bacillus subtilis, $\mathrm{T}=$ Trichoderma viride, $\mathrm{R}=$ Rhizoctonia solani, $\mathrm{F}=\mathrm{F}$. oxysporum, RB=Rhizoctonia solani+Bacillus subtilis, $\mathrm{RT}=$ Rhizoctonia solani+Trichoderma viride, $\mathrm{FB}=\mathrm{F}$. oxysporum+Bacillus subtilis and $\mathrm{FT}=F$. oxysporum+Trichoderma viride.

Table 6: Effect of Bacillus subtilis and Trichoderma viride on the growth parameters
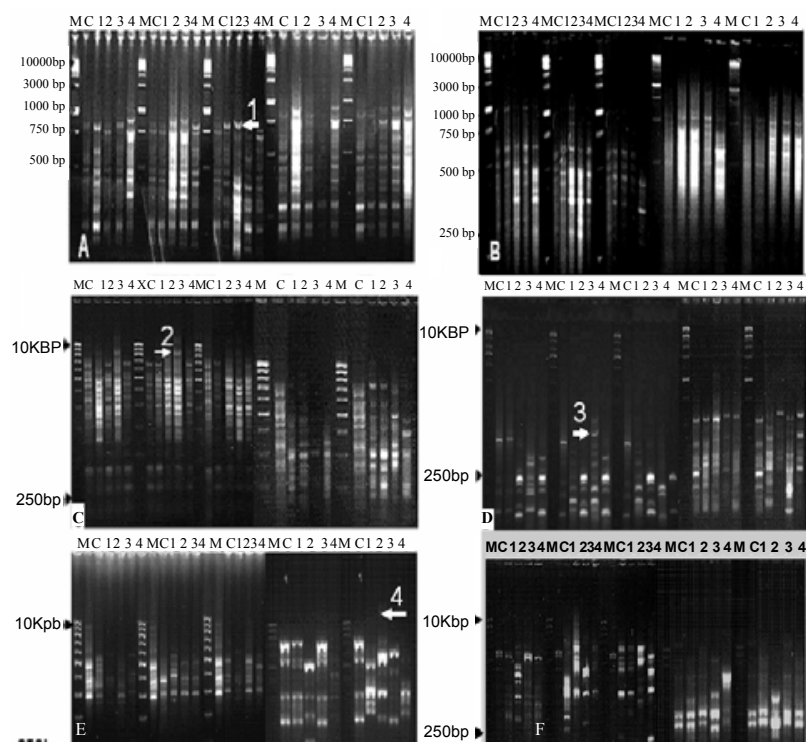

Figure 1: Differential display using chitinase-based primer (A: Chi 15, B: Chi 25, C: EZ, D: EzA1A13, E: PR1 and F: PR2). M: $10 \mathrm{Kbp}$ DNA marker, C: control, 1: $\mathrm{F}+\mathrm{B}$, Lane 2: $\mathrm{F}+\mathrm{T}$, Lane 3: $\mathrm{R}+\mathrm{B}$, lane $4: \mathrm{R}+\mathrm{T}$. The first four samples collected after 2 hours, the second four samples collected after 4 hours, the third four samples collected after $6 \mathrm{hrs}$, the fourth four samples collected after $8 \mathrm{hrs}$, and the fifth four samples collected after $24 \mathrm{hrs}$. Numbers reefer to the isolated and identified genes (1, Amino Acid/Auxin Permease; 2, Endopolygalacturonase PG; 3, Fructose-1,6 bisphosphatase; 4, Glycosyl transferase group 1; 5, Protein tyrosine kinase). ( $\mathrm{F}=\mathrm{F}$. oxysporum; $\mathrm{R}=$ Rhizoctonia solani; $\mathrm{B}=$ Bacillus subtilis; $\mathrm{T}=$ Trichoderma viride).

that treatment with $B$. subtilis or T. viride significantly decreased the disease severity of tomato plants infected, with either R. solani $R$. solani or F. oxysporum.

Effect of treatments on growth parameters is presented in table 6 . Results obtained indicate that both biological control agents stimulated the growth of tomato plants, compared to either infected or healthy plants. Treatment with $B$. subtilis or $T$. viride significantly increased the growth parameters of tomato plants infected with either $R$. solani or $F$. oxysporum, when compared with the control.

To study the induced defensin genes as a result of application of bioagents, plant samples were collected after 2, 4, 6, 8 and $24 \mathrm{~h}$ post-inoculation, and were subjected to differential display and realtime PCR analysis. PCR differential display was performed using six different primers (Table 1). The most prevalent observation was an 
increase in the genetic variations between the control and the treated plants. Results shown in figure 1 (A, B, C, D, E and F) reveal that many down-regulated (turned off) and up-regulated genes (turned on) were observed in both samples treated with $T$. viride and B. subtilis, at different times.

In case of primer ch25, after $2 \mathrm{~h}$ two up-regulated genes were observed with fragments length 1300 and $1500 \mathrm{bp}$ in sample 4 (plant infected with $R$. solani and T. viride), however, only one gene with fragment length of $700 \mathrm{bp}$ was observed in sample 1 (plant infected with F. oxysporum and B. subtilis). Monomorphic genes were observed, highly expressed in samples 1 and 4, compared with the others. After $4 \mathrm{~h}$ post treatment, high expression level was pragmatic in samples 2 (plant infected with F. oxysporum and T. viride) and sample 3 (plant infected with $R$. solani and B. subtilis), and after $6 \mathrm{~h}$, in sample 3 . Moreover, $8 \mathrm{~h}$ post inoculation induced expression level in samples 1 and 4 , however this induction was approached after $24 \mathrm{~h}$ in samples 3 and 4 . Genes with fragment length $1700 \mathrm{bp}$ emerged in samples 2 and 4, but one gene with MW 300 bp was observed in sample 4 only. Primer chi15 was succeeded to differentiate the examined samples. In case of primer EZ, only one up-regulated gene with fragment length 7000 bp was obtained in sample 3 . The same gene with the same fragment length was experiential after $4 \mathrm{~h}$ in samples 2 and 3 . On the other hand, three down regulation genes were noticed in all examined samples, compared with control, these genes were with fragment length $7 \mathrm{kbp}$, $6.5 \mathrm{kbp}$ and $50 \mathrm{bp}$, respectively.

The band pattern initiated by primer EzA1A13 demonstrates that, after $2 \mathrm{~h}$, all the scanned genes are polymorphic in the treated samples, compared with control. However, only high expression level was observed in two genes with fragment length $500 \mathrm{bp}$ and $300 \mathrm{bp}$ in sample 4 . But, after $4 \mathrm{~h}$, the same observation was demonstrated in samples 2 and 3 . Three up-regulation genes were induced in sample 2 (1000 and $700 \mathrm{bp}$ ) and $400 \mathrm{bp}$ in sample 3. After $6 \mathrm{~h}$, all genes are polomorphic and the expression level was the same. After $8 \mathrm{~h}$, high expression level was recorded with samples 1,2 and 4, combined with up-regulated gene with fragment length $200 \mathrm{bp}$. After $24 \mathrm{~h}$, high expression was perceived in all evolved genes in samples 2, 3 and 4. In case of primer PR1, after $2 \mathrm{~h}$ post treatment, only one up-regulated gene was obtained in sample 1 with fragment length $500 \mathrm{bp}$, and another upregulated gene was raised in samples 3 and 4 with MW $300 \mathrm{bp}$. After 4 $\mathrm{h}$, two down regulated genes were observed in sample 3 , with fragment length 750 and $500 \mathrm{bp}$. Down regulation of the most scanned genes, especially in samples 3 and 4 after $8 \mathrm{~h}$ post treatment, was common. After $24 \mathrm{~h}$, one up-regulated gene was observed in samples 1 and 3, with fragment length $600 \mathrm{bp}$. Down regulation was observed in genes with fragment length $9 \mathrm{kbp}, 7 \mathrm{kbp}$ and $6 \mathrm{kbp}$ in samples 1, 2, 3 and 4 . In case of PR2, different band pattern was obtained in all samples after $2 \mathrm{~h}$. After $4 \mathrm{~h}$, eight up regulated genes were exhibited (10 kbp to 150 $\mathrm{bp}$ ) in samples 1, 2 and 3 . After $6 \mathrm{~h}$, there was only one up-regulated gene with fragment length $5 \mathrm{kbp}$ was observed in samples 1,2 and 3 ,and two different genes were demonstrated in sample 4, with fragment length $2 \mathrm{kbp}$ and $250 \mathrm{bp}$. A unique band pattern contains up-regulated gene (5 kbp) was obtained in all samples, except sample 4; after $8 \mathrm{~h}$, however, gene with fragment length $3 \mathrm{kbp}$ was observed in sample 2 after 24 hours.

Our results reveal that the relative amounts of mRNA detected from target genes (Chitinase, Defensin 1 and Defensin2), present in samples collected 2, 4, 6, 8 and $24 \mathrm{~h}$ post inoculation for each treatment, were compared with plant infested with $F$. oxysporum and $R$. solani (genetic pool) and uninfected plant (healthy control). Results normalized to $18 \mathrm{~S}$ r RNA gene (Reference gene). Data in figure 2 show that the increase in time incubation after treatment with bio-agents, the increase in Chitinase (PR protein) gene expression in plants. The highest expression of chitinase gene was observed after $24 \mathrm{~h}$ post treatments. The gene expression in treatment of $R$. solani+T. viride after $24 \mathrm{~h}$ was 2.76. But in case of $R$. solani+B. subtilis, chitinase expression was 1.932. The level of gene expression was 1.823 in plants treated with $F$. oxysporum $+T$. viride; however, in plants treated with $F$. oxysporum $+B$. subtilis, the chitnase expression level was 1.681. It is worth to mention that chitinase expression in infested control did not exceed than 0.31 , which is relatively close to the expression level obtained in the healthy plants (0.26).

In this study, two sets of primers were synthesized for two defensin genes based on the Arabidopsis genome, to examine their expression in the tomato plant treated with pathogen, in the presence of the bioagnets. Meanwhile, the definsin 1 gene expression was fluctuated among the tested samples. The highest expression observed after $24 \mathrm{~h}$ in treatments contain F. oxysporum $+B$. subtilis $(0.69$,$) F. oxysporum +T$. viride (0.68) (Figure 3). However, the highest gene expression in case of treatment of $R$. solani+B. subtilis was achieved after 6 h (0.63), and

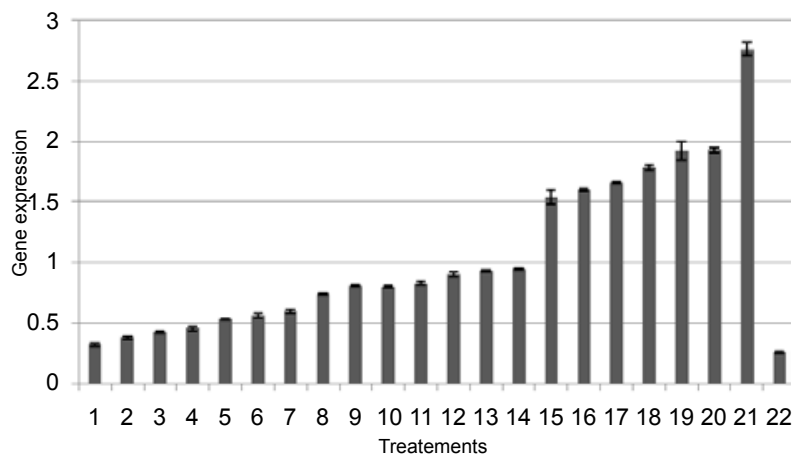

Figure 2: Expression of Chitinase PR gene in tomato roots. 1-control (genetic pool plant life by Rhizoctonia solani and $F$. oxysporum), 2-F+B after $2 \mathrm{~h} ; 3-\mathrm{F}+\mathrm{T}$ after $2 \mathrm{~h} ; 4-\mathrm{R}+\mathrm{B}$ after $2 \mathrm{~h} ; 5-\mathrm{R}+\mathrm{T}$ after $2 \mathrm{~h} ; 6-\mathrm{F}+\mathrm{B}$ after $4 \mathrm{~h} ; 7-\mathrm{F}+\mathrm{T}$ after $4 \mathrm{~h}$; 8- R+B after $4 \mathrm{~h} ; 9-R+T$ after $4 \mathrm{~h} ; 10-\mathrm{F}+\mathrm{B}$ after $6 \mathrm{~h} ; 11-\mathrm{F}+\mathrm{T}$ after $6 \mathrm{~h} ; 12-\mathrm{R}+\mathrm{B}$ after $6 \mathrm{~h}$; 13-R+T after $6 \mathrm{~h}$; 14-F +B after $8 \mathrm{~h} ; 15-\mathrm{F}+\mathrm{T}$ after $8 \mathrm{~h}$; 16-R+B after 8; $17-R+T$ after 8 h; $18-F+B$ after 24 h; 19-F+T after 24 h; 20-R+B after 24; 21$\mathrm{R}+\mathrm{T}$ after $24 \mathrm{~h}$; 22-uninfected plants. ( $\mathrm{F}=\mathrm{F}$. oxysporum; $\mathrm{R}=$ Rhizoctonia solani; $\mathrm{B}=$ Bacillus subtilis; $\mathrm{T}=$ Trichoderma viride).

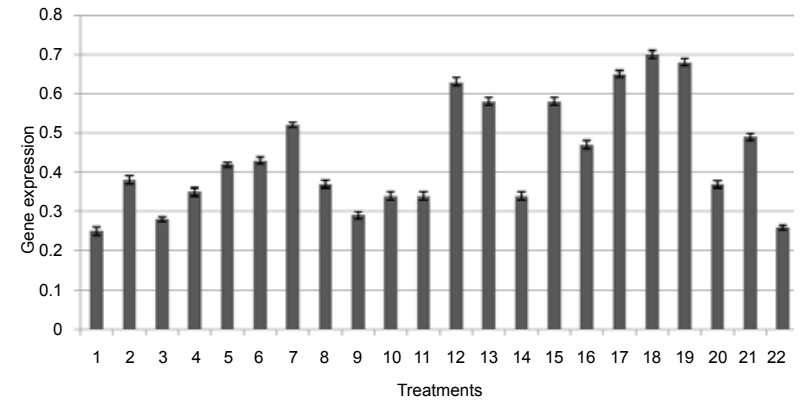

Figure 3: Expression of Defensin 1 gene in tomato roots. 1-control (genetic pool plant life by Rhizoctonia solani and $F$. oxysporum), 2-F+B after $2 \mathrm{~h}$; 3-F+T after $2 \mathrm{~h} ; 4-\mathrm{R}+\mathrm{B}$ after $2 \mathrm{~h} ; 5-\mathrm{R}+\mathrm{T}$ after $2 \mathrm{~h} ; 6-\mathrm{F}+\mathrm{B}$ after $4 \mathrm{~h} ; 7-\mathrm{F}+\mathrm{T}$ after $4 \mathrm{~h} ; 8-\mathrm{R}+\mathrm{B}$ after $4 \mathrm{~h} ; 9-\mathrm{R}+\mathrm{T}$ after $4 \mathrm{~h} ; 10-\mathrm{F}+\mathrm{B}$ after $6 \mathrm{~h} ; 11-\mathrm{F}+\mathrm{T}$ after $6 \mathrm{~h} ; 12-\mathrm{R}+\mathrm{B}$ after $6 \mathrm{~h}$; $13-\mathrm{R}+\mathrm{T}$ after $6 \mathrm{~h} ; 14-\mathrm{F}+\mathrm{B}$ after $8 \mathrm{~h} ; 15-\mathrm{F}+\mathrm{T}$ after $8 \mathrm{~h}$; 16-R+B after $8 ; 17-\mathrm{R}+\mathrm{T}$ after $8 \mathrm{~h} ; 18-\mathrm{F}+\mathrm{B}$ after $24 \mathrm{~h} ; 19-\mathrm{F}+\mathrm{T}$ after $24 \mathrm{~h} ; 20-\mathrm{R}+\mathrm{B}$ after 24; 21-R+T after $24 \mathrm{~h} ; 22$-uninfected plants. $(\mathrm{F}=\mathrm{F}$. oxysporum; $\mathrm{R}=$ Rhizoctonia solani; $\mathrm{B}=$ Bacillus subtilis; $\mathrm{T}=$ Trichoderma viride). 


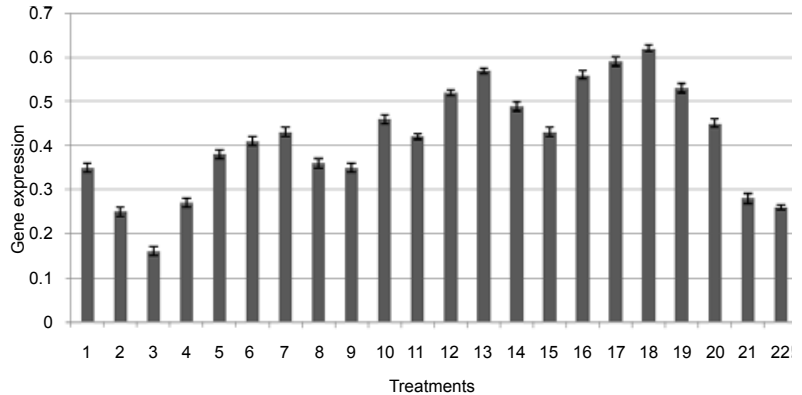

Figure 4: Expression of Defensin 2 gene in tomato roots. 1-control (genetic pool plant life by Rhizoctonia solani and $\mathrm{F}$. oxysporum), 2-F+B after $2 \mathrm{~h} ; 3-\mathrm{F}+\mathrm{T}$ after $2 \mathrm{~h} ; 4-\mathrm{R}+\mathrm{B}$ after $2 \mathrm{~h} ; 5-\mathrm{R}+\mathrm{T}$ after $2 \mathrm{~h} ; 6-\mathrm{F}+\mathrm{B}$ after $4 \mathrm{~h} ; 7-\mathrm{F}+\mathrm{T}$ after $4 \mathrm{~h} ; 8-\mathrm{R}+\mathrm{B}$ after $4 \mathrm{~h} ; 9-R+T$ after $4 \mathrm{~h} ; 10-\mathrm{F}+\mathrm{B}$ after $6 \mathrm{~h} ; 11-\mathrm{F}+\mathrm{T}$ after $6 \mathrm{~h} ; 12-\mathrm{R}+\mathrm{B}$ after $6 \mathrm{~h}$; 13-R+T after $6 \mathrm{~h} ; 14-\mathrm{F}+\mathrm{B}$ after $8 \mathrm{~h} ; 15-\mathrm{F}+\mathrm{T}$ after $8 \mathrm{~h} ; 16-\mathrm{R}+\mathrm{B}$ after $8 ; 17-\mathrm{R}+\mathrm{T}$ after $8 \mathrm{~h} ; 18-\mathrm{F}+\mathrm{B}$ after $24 \mathrm{~h} ; 19-\mathrm{F}+\mathrm{T}$ after $24 \mathrm{~h} ; 20-\mathrm{R}+\mathrm{B}$ after $24 ; 21-\mathrm{R}+\mathrm{T}$ after $24 \mathrm{~h}$; 22- uninfected plants. ( $\mathrm{F}=F$. oxysporum; $\mathrm{R}=\mathrm{R}$. solani; $\mathrm{B}=$ Bacillus subtilis; $\mathrm{T}=$ Trichoderma viride)

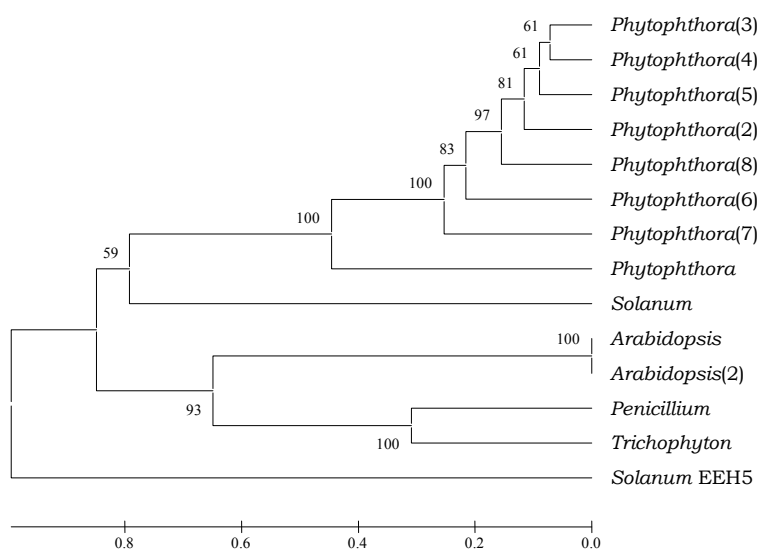

Figure 5: Phylogenetic tree showing evolutionary relationship between Amino Acid/Auxin Permease gene of tomato plants and the others presented in GenBank. The Neighbor-Joining method was used to construct the tree. The numbers on the branches represent bootstrap support for 1,000 replicates. Names refer to the accession number of the nucleotide sequences that encode the corresponding Amino Acid/Auxin Permease genes.

gradually decreased up to 0.38 after $24 \mathrm{~h}$. The gene expression in plants treated with $R$. solani and T. viride T. viride, also show sequentially increase starting after $2 \mathrm{~h}$, until 8 (0.4-0.6), then went down after 24 h $(0.38)$.

Regarding defensin 2, the highest expression was observed in samples treated with $F$. oxysporum and B. subtilis, after $24 \mathrm{~h}$ post inoculation (0.623). But the lower expression level was demonstrated in plants treated with $F$. oxysporum and $T$. viride, after $2 \mathrm{~h}$ post inoculation (0.15). The same expression level was observed in plants treated with $F$. oxysporum $+B$. subtilis and $F$. oxysporum $+T$. viride, after $4 \mathrm{~h}$. Defensin 2 gene expression was induced in plants treated with $R$. solani + B. subtilis and $R$. solani+T. viride, after 8 and $6 \mathrm{~h}$, respectively in the same level (0.57). This expression gradually decreased into 0.3 after $24 \mathrm{~h}$, as a result of application of $R$. solani+T. viride (Figure 4).

The four up-regulated genes which randomly selected (indicated with bold arrows on the figures) showed low similarity with their alleles listed in gene bank, with identity not exceeding more than $47 \%$, which insure that all of them are new genes. Amino acid/auxin primase gene showed similarity with the other ones isolated from Phytophthora,
Solanum, Arabidopsis, Penicillium and Trichophyton, with different identity. The gene was grouped with Phytophthora genes, and it was considered as outer group for Solanum and Arabidopsis (Figure 5). Data in figure 6 revealed that the nine aligned genes were grouped into two main groups which had one ancestor. The first group contains the obtained gene, and other one isolated from Glomerella and the second group, included the rest of genes.

The isolated fructose 1,6 biphosphatase gene showed similarity with other genes isolated from tomato, yeast, and exons 3,4,6,7 in human (Figure 7). A phylogenetic tree was constructed for the isolated glyocel transferase group 1 gene, with other 11 different genes isolated from different organisms, and the obtained gene grouped as a separate group (Figure 8).

\section{Discussion}

In vitro test showed that $B$. subtilis and $T$. viride greatly suppressed the growth of the two pathogens. The reduction in linear growth was $79.72 \%$ in case of R. solani and $79.41 \%$, in case of F. oxysporum, when $T$. viride was applied. Trichoderma spp. is well known for their antagonism against several soil-phytopathogens. The main mechanisms of action involved in the antagonism of Trichoderma are mycoparasitism, secretion of bioactive molecules (i.e. antibiotics and cell wall degrading enzymes), competition for space and nutrients and stimulation of the plant's defensive capacity [13]. Also, Bacillus spp. was used as biological control agents against many soil borne pathogens. It was mentioned to

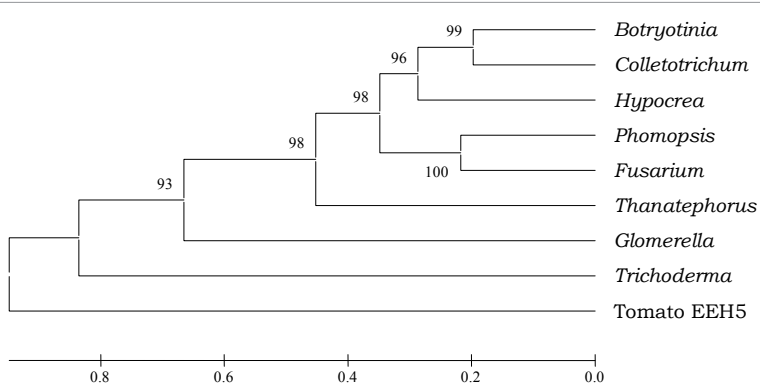

Figure 6: Phylogenetic tree showing evolutionary relationship between endopolygalacturonase gene of tomato plants and the others presented in GenBank. The Neighbor-Joining method was used to construct the tree. The numbers on the branches represent bootstrap support for 1,000 replicates. Names refer to the accession number of the nucleotide sequences that encode the corresponding endo-polygalacturonase genes.

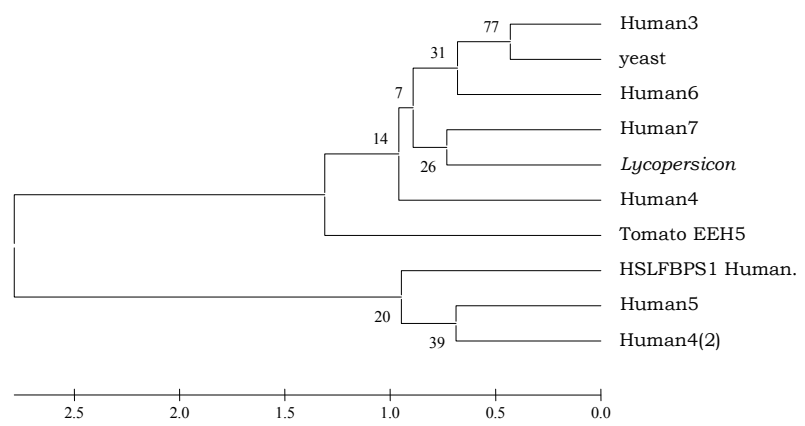

Figure 7: Phylogenetic tree showing evolutionary relationship between Fructose 1-6-biphosphatase gene of tomato plants and the others presented in GenBank. The Neighbor-Joining method was used to construct the tree. The numbers on the branches represent bootstrap support for 1,000 replicates. Names refer to the accession number of the nucleotide sequences that encode the corresponding Fructose 1-6-biphosphatase genes. 


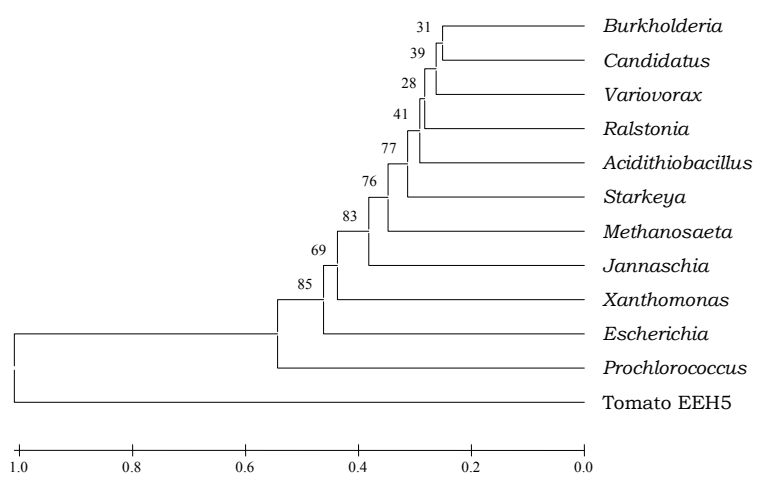

Figure 8: Phylogenetic tree showing evolutionary relationship between glycotransferase gene of tomato plants and the others presented in GenBank The Neighbor-Joining method was used to construct the tree. The numbers on the branches represent bootstrap support for 1,000 replicates. Names refer to the accession number of the nucleotide sequences that encode the corresponding glycotransferase genes.

offer several advantages over other bacteria, for protection against root pathogens, because of their ability to form endospores, and because of the broad-spectrum activity of their antibiotics [14]. B. subtilis produces several kinds of antibiotics, e.g. bacillomycin, iturin, mycosubtilin, bacilysin, fengymycin, and mycobacillin [15]

The most prevalent observation come from differential display study, was an increase in the genetic variations between the control and the treated plants. It was shown that many down-regulated (turned off) and up-regulated genes (turned on) were observed in both samples treated with T. viride and B. subtilis, at different times. In case of primer ch25, the most induced/suppressed genes were pragmatic with samples 1 and 4 . But with EZ primer, the induced genes were observed with samples 2 and 3. Primer EzA1A13 showed three unregulated genes in sample 4 and high gene expression with samples 1, 2, 3 and 4 . With primer PR1, the induced /suppressed genes was demonstrated with samples 3 and 4 . On the other hand, PR2 primer revealed high expression level in all obtained genes was perceived with all the examined samples.

Our results are partially in agreement with those of Benito et al. [10], who studied the differential display expression in tomato plants induced by Botrytis cinerea. They also studied the different plant genes induced by fungal infection, through different patho-genes. By comparative analysis expression patterns of healthy tomato leaves and tomato leaves infected with two different pathogens, "either Phytophthora infestans or tobacco necrosis virus (TNV)", they found that plant defense genes induced in response to the tested pathogen(s). Kiba et al. [16] used differential display technique to isolate fragments of genes that are regulated in tobacco, by virulent strains of $R$. solanacearum OE1- 1 . The present results suggest that the cDNA and method presented in this study provide a valuable resource for functional genomics analysis of pathogen-bioagent-plant interactions.

An important step in understanding the molecular basis of microbeplant interactions is isolation and characterization of genes, which are regulated in compatible or incompatible combinations. In this context, Godiard et al. [17] reported that cDNA clones corresponding to mRNA accumulated during the early phase of the hypersensitive response (HR), in suspension cultured tobacco cells challenged with a non-pathogenic strain of $R$. solanacearum. However, there have been few other informative reports of expression profiling and functional analysis of genes, related to $R$. solanacearum-plant interactions.
Development of real-time PCR (RT-PCR) has provided a powerful tool for pathogen monitoring. It allows detecting the pathogen earlier than symptoms of the disease appear on the plants. With the use of RT-PCR, it is possible to perform a semiquantification of fungal pathogens, such as F. oxysporum, Fusarium solani, Pythium ultimum and R. solani in a single assay [18]. Our results revealed that the relative amounts of mRNA detected from target genes (Chitinase, Defensin 1 and Defensin2), present in samples collected 2, 4, 6, 8 and $24 \mathrm{~h}$ post inoculation for each treatment, were compared with plant infested with F. oxysporum and R. solani (genetic pool) and uninfested plant (healthy control).

The chitinase gene was gradually increased in all examined samples and reached its peak with samples 21 . But, the expression of the F1 gene was fluctuated, but the highest expression level was precieved in samples 18 and 19. Gene F2 showed the same observation obtained by the F1 gene. Chitinases are key enzymes involved in plant-microbe interactions, and are grouped in the pathogen-related protein type three families (PR-3). Five classes of plant chitinases have been proposed based on their peptidic sequences, conserved domains and specific activities [19]. Because chitin is a primary structural component of the wall of all true fungi, chitinases are considered to play a major role during pathogenic plant-fungal interactions [20]. The combined expression of chitinases with other plant-defense proteins, such as glucanases and ribosome-inactivating proteins further enhances the plant's resistance to fungal attack. The time for chitinase induction is also dependent on the specific pathogen-host interaction, and varies from minutes to $15-20 \mathrm{~h}$ [20].

Plant activation of host defense against pathogenic microbes requires significant host transcriptional reprogramming [21]. Moreover, within the subset of genes that are regulated by both pathogens, many genes show inverse regulation. Stotz et al. [22] studied the expression of the defensin gene DEF2 in tomato, and they found that defensin mRNA expression processing is differentially regulated in developing flowers. Antisense suppression or constitutive over expression of DEF2 reduces pollen viability and seed production. Furthermore, over expression of DEF2 pleiotropically alters the growth of various organs, and enhances foliar resistance to the fungal pathogen Botrytis cinerea. Most plant defensins are active against fungi [23].

PG1 is the major endopolygalacturonase of the vascular wilt pathogen, Fusarium oxysporum [24]. The tomato vascular wilt pathogen, Fusarium oxysporum f. sp. lycopersici, produces an array of pectinolytic enzymes that may contribute to penetration and colonization of the host plant [24]. Here, in our study, we isolated this gene as up-regulated gene from tomato plant leaves infested with Fusarium oxysporum. Different nine Endopolygalacturonase PG1 genes were allined with the obtained gene. On the other hand, $F$. oxysporum causes vascular wilt disease on a wide variety of crops, and produces a wide variety of extracellular cell wall degrading enzymes (CWDEs), including xylanases, cellulases, proteases, pectate lyases, and exo- and endoPGs. To counteract the action of PGs, plants express polygalacturonase-inhibiting proteins (PGIPs), that have been shown to inhibit a variety of PGs with different inhibition kinetics, both competitive and noncompetitive [25].

Transcript analysis has been effectively employed to probe defense responses induced by elicitors, including yeast activated tomato genes encoding SAR-dependent PRs (chitinase and glucanase), cytochrome P450s and cell wall loosening enzymes (e.g. expansin, xyloglucan endoglycosl transferase, polygalacturonase) [26]. In Arabidopsis, transcriptional analysis has identified elicitor induced acclamatory 
Citation: Hafez EE, Hashem M, Balbaa MM, El-Saadani MA, Ahmed SA (2013) Induction of New Defensin Genes in Tomato Plants via PathogensBiocontrol Agent Interaction. J Plant Pathol Microb 4: 167 doi:10.4172/2157-7471.1000167

responses to stress, such as recovery of the cell redox balance (glutathione transferase, UDP glycosyltransferase and glutaredoxins), intracellular stress signaling and improved pathogen recognition [27]. While activation of defense responses by plant elicitors can protect against pathogens, an inhibition of the biosynthesis of photosynthetic pigments and photosynthetic activity reducing plant productivity can also occur [28].

Zhu-Salzman et al. [29] identified an LRR-containing glycoprotein sequence that is differentially expressed in leaves of Sorghum bicolor (L.) infested by $S$. graminum. LRR-containing glycoproteins are extracellular, membrane-anchored compounds that in some cases recognize specific tomato leaf mold pathogen, Cladosporium fulvum (Cf)-encoded virulence gene products. Results of Rooney et al. [30] indicated that Cf-2 and its Avr2 protein trigger a hypersensitive (resistance) response, that also requires an extracellular tomato cysteine protease Rcr3. The binding of Avr2 with and resulting Rcr3 inhibitions proposed as the event that enables the Cf- 2 protein to activate a resistance response. A sequence similar to the Xa1 gene encoding the protein that confers resistance to bacterial blight, by recognizing a pathogen elicitor, was also found by Park et al. [31], to be up-regulated by S. graminum feeding on sorghum.

Signal perception through cell-surface receptors is a common feature among living organisms. In plants, several different types of cell-surface receptors perceive diverse signals and stimuli from the environment. Some of these receptors, such as the receptor histidine kinases in plants that mediate responses to the hormones ethylene [32], and cytokinin, have not yet been found in metazoan genomes. The functions of plant RLKs can be divided into two broad categories. The first category includes RLKs, involved in the control of plant growth and development, under normal growth conditions [33]. The second category includes RLKs involved in plant-microbe interactions and stress responses. The evolutionary relationships between these proteins, and what appear to be overlapping functions, suggest that the kinases ancestral to these two gene families may have been involved in these two "functions", before the divergence between plants and animals [33].

\section{References}

1. De Curtis F, Lima G, Vitullo D, De Cicco V (2010) Biocontrol of Rhizoctonia solani and Sclerotium rolfsii on tomato by delivering antagonistic bacteria through a drip irrigation system. Crop Prot 29: 663-670.

2. Roberts DP, Lohrke SM, Meyer SLF, Buyer JS, Bowers JH, et al. (2005) Biocontrol agents applied individually and in combination for suppression of soil borne diseases of cucumber. Crop Prot 24: 141-155.

3. Shoresh M, Yedidia I, Chet I (2005) Involvement of Jasmonic acid/ethylene signaling pathway in the systemic resistance induced in cucumber by Trichoderma asperellum T203. Phytopathology 95: 76-84.

4. Shoresh M, Harman GE (2008) The molecular basis of shoot responses of maize seedlings to Trichoderma harzianum T22 inoculation of the root: a proteomic approach. Plant Physiol 147: 2147-2163.

5. Alfano G, Ivey ML, Cakir C, Bos JI, Miller SA, et al. (2007) Systemic modulation of gene expression in tomato by Trichoderma hamatum 382. Phytopathology 97: $429-437$

6. Bailey BA, Bae H, Strem MD, Roberts DP, Thomas SE, et al. (2006) Fungal and plant gene expression during the colonization of cacao seedlings by endophytic isolates of four Trichoderma species. Planta 224: 1449-1464.

7. Yan LIU, Jing TAO, Yujun YAN, Bin LI, Hui LI, et al. (2011) Biocontrol efficiency of Bacillus subtilis SL-13 and characterization of an antifungal chitinase. Chin J Chem Eng 19: 128-134

8. Ongena M, Duby F, Rossignol F, Fauconnier ML, Dommes J, et al. (2004) Stimulation of the lipoxygenase pathway is associated with systemic resistance induced in bean by a nonpathogenic Pseudomonas strain. Mol Plant Microbe Interact 17: 1009-1018

9. Hafez EE, Elbestawy E (2009) Molecular characterization of soi microorganisms: Effect of industrial pollution on distribution and biodiversity. World J Microbiol Biotechnol 25: 215-224.

10. Benito EP, Prins T, van Kan JA (1996) Application of differential display RT-PCR to the analysis of gene expression in a plant-fungus interaction. Plant Mol Biol 32: $947-957$

11. Thompson JD, Higgins DG, Gibson TJ (1994) CLUSTAL W: improving the sensitivity of progressive multiple sequence alignment through sequence weighting, position-specific gap penalties and weight matrix choice. Nucleic Acids Res 22: 4673-4680.

12. Kumar S, Tamura K, Nei M (2004) MEGA3: Integrated software for molecular evolutionary genetics analysis and sequence alignment. Brief Bioinform 5: 150163

13. Van der Ent S, Verhagen BW, Van Doorn R, Bakker D, Verlaan MG, et al (2008) MYB72 is required in early signaling steps of rhizobacteria-induced systemic resistance in Arabidopsis. Plant Physiol 146: 1293-1304.

14. Cavaglieri L, Orlando J, Rodríguez MI, Chulze S, Etcheverry M (2005) Biocontrol of Bacillus subtilis against Fusarium verticillioides in vitro and at the maize root level. Res Microbiol 156: 748-754.

15. Trotel-Aziz P, Couderch M, Biagianti S, Aziz A (2008) Characterization of new bacterial biocontrol agents Acinetobacter, Bacillus, Pantoea and Pseudomonas spp. mediating grapevine resistance against Botrytis cinerea. Environ Exp Bot 64: 21-32.

16. Kiba T, Henriques R, Sakakibara H, Chua NH (2007) Targeted degradation of Pseudo-response regulator 5 by an SCFZTL complex regulates clock function and photomorphogenesis in Arabidopsis thaliana. Plant Cell 19: 2516-2530.

17. Godiard L, Froissard D, Fournier J, Axelos M, Marco Y (1991) Differentia regulation in tobacco cell suspensions of genes involved in plant-bacteria interactions by pathogen-related signals. Plant Mol Biol 17: 409-413.

18. Lievens B, Brouwer M, Vanachter AC, Levesque CA, Cammue BP, et al. (2005) Quantitative assessment of phytopathogenic fungi in various substrates using a DNA macroarray. Environ Microbiol 7: 1698-1710.

19. Selitrennikoff CP (2001) Antifungal proteins. Appl Environ Microbiol 67: 2883 2894

20. Bravo JM, Campo S, Murillo I, Coca M, San Segundo B (2003) Fungus- and wound-induced accumulation of mRNA containing a class II chitinase of the pathogenesis-related protein 4 (PR-4) family of maize. Plant Mol Biol 52: 745 759.

21. van Esse HP, Fradin EF, de Groot PJ, de Wit PJ, Thomma BP (2009) Tomato transcriptional responses to a foliar and a vascular fungal pathogen are distinct. Mol Plant Microbe Interact 22: 245-258.

22. Stotz HU, Spence B, Wang Y (2009) A defensin from tomato with dual function in defense and development. Plant Mol Biol 71: 131-143.

23. Thevissen K, Warnecke DC, François IE, Leipelt M, Heinz E, et al. (2004) Defensins from insects and plants interact with fungal glucosylceramides. J Biol Chem 279: 3900-3905.

24. Piffanelli P, Devoto A, Schulze-Lefert $P$ (1999) Defense signalling pathways in Cereals. Curr Opin Plant Biol 2: 295-300.

25. Sicilia F, Fernandez-Recio J, Caprari C, De Lorenzo G, Tsernoglou D, et al (2005) The polygalacturonase-inhibiting protein PGIP2 of Phaseolus vulgaris has evolved a mixed mode of inhibition of endopolygalacturonase PG1 of Botrytis cinerea. Plant Physiol 139: 1380-1388.

26. Jiang F, Zheng X, Chen J (2009) Microarray analysis of gene expression profile induced by the biocontrol yeast Cryptococcus laurentii in cherry tomato fruit. Gene 430: 12-16.

27. Blanco F, Salinas P, Cecchini NM, Jordana X, Van Hummelen P, et al. (2009) Early genomic responses to salicylic acid in Arabidopsis. Plant Mol Biol 70 79-102.

28. Frick UB, Schaller A (2002) cDNA microarray analysis of fusicoccin-induced changes in gene expression in tomato plants. Planta 216: 83-94. 
Citation: Hafez EE, Hashem M, Balbaa MM, El-Saadani MA, Ahmed SA (2013) Induction of New Defensin Genes in Tomato Plants via PathogensBiocontrol Agent Interaction. J Plant Pathol Microb 4: 167 doi:10.4172/2157-7471.1000167

Page 9 of 9

29. Zhu-Salzman K, Salzman RA, Ahn JE, Koiwa H (2004) Transcriptional regulation of sorghum defense determinants against a phloem-feeding aphid. Plant Physiol 134: 420-431.

30. Rooney HC, Van't Klooster JW, van der Hoorn RA, Joosten MH, Jones JD, et al. (2005) Cladosporium Avr2 inhibits tomato Rcr3 protease required for Cf-2 dependent disease resistance. Science 308: 1783-1786.

31. Park SJ, Huang Y, Ayoubi P (2005) Identification of expression profiles of sorghum genes in response to greenbug phloem-feeding using cDNA subtraction and microarray analysis. Planta 223: 932-947.

32. Bleecker AB, Kende $H$ (2000) Ethylene: a gaseous signal molecule in plants Annu Rev Cell Dev Biol 16: 1-18.

33. Shiu SH, Bleecker AB (2001) Receptor-like kinases from Arabidopsis form monophyletic gene family related to animal receptor kinases. Proc Nat Acad Sci U S A 98: 10763-10768. 